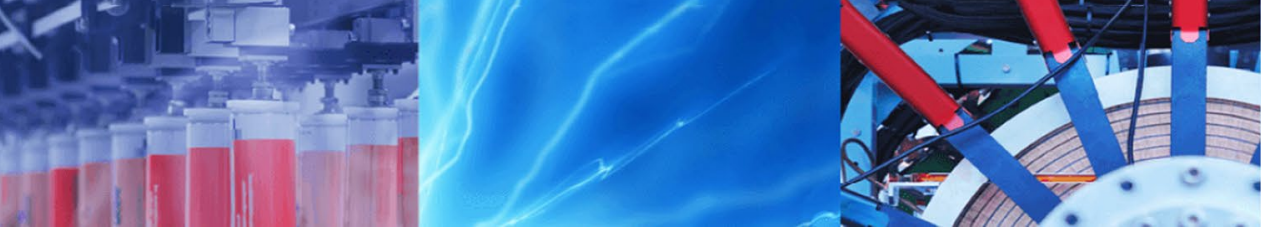

Research Article

\title{
Facile synthesis and antibacterial applications of cuprous oxide/ bovine serum albumin hierarchical nanocomposite particles
}

\author{
Shuyan Zhao ${ }^{1} \cdot$ Yujie Gao $^{1} \cdot$ Jinhui Tan $^{2} \cdot$ Yuntao Zhu $^{2} \cdot$ Xiaohong Ying $^{2} \cdot$ Mengmeng Zhang $^{2} \cdot$ Xufeng Yu $^{2} \cdot$ Bo You $^{1}$
}

(c) Springer Nature Switzerland AG 2019

\begin{abstract}
A facile method to prepare cuprous oxide/bovine serum albumin $\left(\mathrm{Cu}_{2} \mathrm{O} / \mathrm{BSA}\right)$ hierarchical nanocomposite particles (NCPs) through imitating biomineralization is presented. BSA acted as the structure-directing agents, guiding the nucleation, growth and assembly of $\mathrm{Cu}(\mathrm{OH})_{2}$ at binding sites to construct the hierarchical structure and then $\mathrm{Cu}_{2} \mathrm{O} / \mathrm{BSA}$ NCPs were achieved. The synthesized nanocomposite with hierarchical structure exhibited excellent antibacterial performance. The products obtained were characterized with XRD, TEM, FTIR, EDX and XPS to investigate the formation mechanism of $\mathrm{Cu}_{2} \mathrm{O} / \mathrm{BSA}$ hierarchical structure. $\mathrm{Cu}_{2} \mathrm{O} / \mathrm{BSA} \mathrm{NCPs}$ with size of $20-50 \mathrm{~nm}$ built up by several $6-7 \mathrm{~nm} \mathrm{Cu}_{2} \mathrm{O}$ nanocrystals with $\mathrm{BSA}$ showed better antibacterial performance in the comparative experiments, which was attributed to the special structure and good biocompatibility of the $\mathrm{Cu}_{2} \mathrm{O} / \mathrm{BSA} \mathrm{NCPs}$. And the possible mechanism was presented to explain the excellent antibacterial properties of $\mathrm{Cu}_{2} \mathrm{O} / \mathrm{BSA} \mathrm{NCPs}$.
\end{abstract}

Keywords Biomineralization - Cuprous oxide - Bovine serum albumin · Hierarchical nanocomposite particles · Antibacterial

\section{Introduction}

In nature, biological systems can control the nucleation, growth and assembly of crystals precisely and efficiently by biomineralization [1]. Many kinds of crystals with specific shape and size can be obtained [2]. Therefore, biomineralization has attracted the attentions of many researchers. Numerous kinds of biomolecules and organic matrixes have been used as templates to simulate the biomineralization process during the synthesis of functional materials [3-6]. Bovine serum albumin (BSA) is a common and commercially available protein with good solubility and biocompatibility. BSA is available to interact with a variety of metal ions as a biomacromolecule with various functional groups, such as amino and carboxyl groups. Thus, it is often used as structure-directing reagents during the biomineralization process. Xie et al. [7] synthesized gold nanoclusters consisted of 25 gold atoms by BSA. The structure showed good stability, biocompatibility and high quantum yield. Yilmaz et al. [8] prepared $\mathrm{BSA}-\mathrm{Cu}(\mathrm{II})$ hybrid nanoflowers by biomineralization and the products were successfully used as absorbent for solid phase extraction. $\mathrm{SiO}_{2}$ nanoparticles were modified with $\mathrm{BSA}$ by Mallakpour et al. [9]. The modified $\mathrm{SiO}_{2}-\mathrm{BSA}$ nanoparticles had good dispersion in PVC matrix and the achieved nanocomposite film were improved in the optical, mechanical and thermal characteristics. The grain size and special structure of synthetic materials can be controlled effectively by using BSA as the structure-directing

Electronic supplementary material The online version of this article (https://doi.org/10.1007/s42452-019-0963-9) contains supplementary material, which is available to authorized users.

$\triangle$ Bo You, youbo@fudan.edu.cn | 1 Department of Materials Science and the Advanced Coatings Research Center of Ministry of Education of China, Fudan University, Shanghai 200433, People's Republic of China. ${ }^{2}$ Zhejiang Academy of Science and Technology for Inspection and Quarantine (Jiaxing), Jiaxing 314000, Zhejiang, People's Republic of China.

SN Applied Sciences (2019) 1:917| https://doi.org/10.1007/s42452-019-0963-9

Received: 19 April 2019 / Accepted: 20 July 2019 / Published online: 25 July 2019 
reagent. In addition, the obtained materials exhibit good stability and compatibility.

Cuprous oxide $\left(\mathrm{Cu}_{2} \mathrm{O}\right)$ is a semiconductor material with good redox and photoelectric properties. Therefore, it has broad applications in catalysts, water splitting, antifouling, gas sensing and solar cells [10-14]. Copper owns lower toxicity and cost, so $\mathrm{Cu}_{2} \mathrm{O}$ is often used as an antibacterial agent [15-17]. In order to improve the antibacterial properties of $\mathrm{Cu}_{2} \mathrm{O}$, a lot of studies has been carried out. Some researchers controlled the shape and morphology of $\mathrm{Cu}_{2} \mathrm{O}$ to enhance antibacterial activity [18, 19]. Wang et al. [20] synthesized $\mathrm{Cu}_{2} \mathrm{O}$ octahedrons, cubes, hollow spheres and flowers, and the hierarchical flowerlike microstructures consisted of nanosheets displayed the best antibacterial property. Some researchers added other materials (such as $\mathrm{Ag}$ and $\mathrm{TiO}_{2}$ ) and fabricated composites with specific structures [21, 22]. The added materials might play the synergism with $\mathrm{Cu}_{2} \mathrm{O}$ to improve the antibacterial performance. However, most researchers took only one of these two methods to improve antibacterial properties of $\mathrm{Cu}_{2} \mathrm{O}$.

Because of the high accuracy and efficiency of biomineralization, some biomolecules have been used as capping and stabilizing agents during the synthesis of $\mathrm{Cu}_{2} \mathrm{O}[23$, 24]. However, the structure-directing mechanism was not studied in detail in the previous researches. Moreover, the effects of biomolecules during the synthesis process were discussed but the functions of biomolecules in the antibacterial process failed to be considered.

In this work, a novel synthesis of cuprous oxide/bovine serum albumin $\left(\mathrm{Cu}_{2} \mathrm{O} / \mathrm{BSA}\right)$ hierarchical nanocomposite particles (NCPs) with size of $20-50 \mathrm{~nm}$ built up by several 6-7 nm $\mathrm{Cu}_{2} \mathrm{O}$ nanocrystals and $\mathrm{BSA}$ is reported. Furthermore, a possible mechanism of the nucleation, growth and assembly of $\mathrm{Cu}_{2} \mathrm{O} / \mathrm{BSA}$ NCPs is provided. A hierarchical structure is the higher dimensional structure composed of low dimensional nanomaterials [25]. The designed hierarchical structure possesses both the properties of the primary and secondary structures [26]. Therefore, the $\mathrm{Cu}_{2} \mathrm{O} / \mathrm{BSA}$ hierarchical structure exhibited excellent antibacterial performance which was due to the combination of the special $\mathrm{Cu}_{2} \mathrm{O} / \mathrm{BSA}$ hierarchical structure and good biocompatibility of BSA.

\section{Experimental section}

\subsection{Materials}

Copper acetate $\left(\mathrm{Cu}(\mathrm{Ac})_{2} \cdot \mathrm{H}_{2} \mathrm{O}\right)$, sodium hydroxide $(\mathrm{NaOH})$, ascorbic acid, cuprous oxide $\left(\mathrm{Cu}_{2} \mathrm{O}\right)$, potassium dihydrogen phosphate $\left(\mathrm{KH}_{2} \mathrm{PO}_{4}\right)$ were purchased from Guoyao Chemical Reagent Co (China). Bovine serum albumin (BSA, $96 \mathrm{wt} \%)$, cuprous chloride $(\mathrm{CuCl})$ were purchased from
Shanghai Aladdin Biochemical Technology Co (China). Ethanol was purchased from Shanghai Titan Scientific Co (China). All chemicals were analytical-grade regents and used without further purification. Staphylococcus aureus ATCC 25923 (S. aureus) and Escherichia coli ATCC 25922 (E. coli) were supplied by Jiaxing Entry-Exit Inspection and Quarantine Bureau (China). Nutrient broth, nutrient agar, defiber sheep blood, Baird-Parker medium base (CM302) and GCM105 eosin methylene blue agar (EMB) were purchased from Beijing Land Bridge Technology Co (China).

\subsection{Synthesis of $\mathrm{Cu}_{2} \mathrm{O} / \mathrm{BSA} \mathrm{NCPs}$}

A certain amount of BSA $(0.1 \mathrm{~g}, 0.2 \mathrm{~g}, 0.3 \mathrm{~g}$ and $0.4 \mathrm{~g})$ was dissolved in $54 \mathrm{~g}$ of distilled water at $37^{\circ} \mathrm{C}$ under stirring. $0.1 \mathrm{~g} \mathrm{Cu}(\mathrm{AC})_{2} \cdot \mathrm{H}_{2} \mathrm{O}$ was dissolved in $60 \mathrm{~g}$ of distilled water and then the solution was added into the above BSA solution under vigorous stirring. The solution changed to white. After mixed for $10 \mathrm{~min}, 2 \mathrm{~mL} \mathrm{NaOH}\left(1 \mathrm{~mol} \mathrm{~L}^{-1}\right)$ was added and purple solution was obtained. Then $0.2 \mathrm{~g}$ ascorbic acid was dissolved in $4 \mathrm{~g}$ of distilled water and added into the above purple solution to reduce $\mathrm{Cu}(\mathrm{II})$ to $\mathrm{Cu}(\mathrm{I})$. The color of solution became yellow gradually. The mixed solution was stirred at $37^{\circ} \mathrm{C}$ for different time $(1 \mathrm{~min}, 10 \mathrm{~min}$, $30 \mathrm{~min}$, and $60 \mathrm{~min}$ ) and the $\mathrm{Cu}_{2} \mathrm{O} / \mathrm{BSA}$ NCPs dispersion was achieved. Finally, the $\mathrm{Cu}_{2} \mathrm{O} / \mathrm{BSA}$ NCPs sample was collected and washed several times with distilled water and ethanol and then dried for $24 \mathrm{~h}$. Meanwhile, $\mathrm{Cu}_{2} \mathrm{O}$ samples without the addition of $\mathrm{BSA}\left(\mathrm{BSA}-\mathrm{O}-\mathrm{Cu}_{2} \mathrm{O}\right)$ were prepared for comparing. The samples produced under different conditions were showed in Table 1. All the experimental steps of the other samples were consistent with the synthetic process of $\mathrm{Cu}_{2} \mathrm{O} / \mathrm{BSA} \mathrm{NCPs}$.

\subsection{Antibacterial performance test}

$34.0 \mathrm{~g}$ of $\mathrm{KH}_{2} \mathrm{PO}_{4}$ and $500 \mathrm{~mL}$ distilled water were mixed and then the $\mathrm{pH}$ was adjusted by $175 \mathrm{~mL}$ of $\mathrm{NaOH}$ $\left(1 \mathrm{~mol} \mathrm{~L}^{-1}\right)$. The mixed solution was subsequently diluted to $1000 \mathrm{~mL}$ with distilled water. $1.25 \mathrm{~mL}$ of above solution

Table 1 Samples of $\mathrm{Cu}_{2} \mathrm{O} / \mathrm{BSA}$ NCPs produced under different conditions

\begin{tabular}{lcl}
\hline Sample & Reaction time (min) & $\begin{array}{l}\text { Amount } \\
\text { of BSA } \\
(\mathrm{g})\end{array}$ \\
\hline $\mathrm{BSA}-\mathrm{Cu}_{2} \mathrm{O}-1$ & 1 & 0.2 \\
$\mathrm{BSA}-0-\mathrm{Cu}_{2} \mathrm{O}$ & 60 & 0 \\
$\mathrm{BSA}-0.1-\mathrm{Cu}_{2} \mathrm{O}$ & 60 & 0.1 \\
$\mathrm{BSA}-\mathrm{Cu}_{2} \mathrm{O}$ & 60 & 0.2 \\
$\mathrm{BSA}-0.3-\mathrm{Cu}_{2} \mathrm{O}$ & 60 & 0.3 \\
$\mathrm{BSA}-0.4-\mathrm{Cu}_{2} \mathrm{O}$ & 60 & 0.4 \\
\hline
\end{tabular}


was further diluted to $1000 \mathrm{~mL}$ with distilled water and autoclaved to obtain phosphate buffer solution (PBS). S. aureus and E. coli were activated on blood agar and cultivated in nutrient broth.

Equivalent $\mathrm{BSA}-0-\mathrm{Cu}_{2} \mathrm{O}, \mathrm{BSA}-\mathrm{Cu}_{2} \mathrm{O}$, commercial $\mathrm{Cu}_{2} \mathrm{O}$ and $\mathrm{CuCl}$ were added to PBS containing equivalent $\mathrm{S}$. aureus and $E$. coli separately to test the antimicrobial properties of different samples. The final concentration of sam-

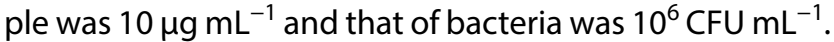
Different solutions above were placed in orbital shaker at $37^{\circ} \mathrm{C}$ for different durations. And then $100 \mu \mathrm{L}$ of $S$. aureus and $E$. coli reaction solution were plated on $\mathrm{CM} 302$ and EMB agar plates, respectively, and incubated at $37^{\circ} \mathrm{C}$ for $24 \mathrm{~h}$ to obtain plate counting. Each group was repeated for three times.

Different samples were dissolved in PBS solution which is similar with antimicrobial tests but without bacteria and the samples were shook in the orbital shaker for copper release studies. The concentrations of ion release for different durations were measured by ICP-AES.

\subsection{Characterization}

Transmission electron microscopy (TEM) was performed on a FEI Tecnai G2 20 TWIN microscope. Field-emission scanning electron microscopy (FESEM) and energy dispersive X-ray (EDX) were obtained on a Zeiss Ultra 55 fieldemission scanning electron microscope. High-resolution transmission electron microscopy (HRTEM) and selectarea electron diffraction (SAED) were measured on a JEOL JEM-2010 microscope. Powder X-ray diffraction (XRD) was tested on a Bruker D8A Advance. Fourier transform infrared spectroscopy (FTIR) was achieved on a Thermo Fisher Nicolet Nexus 470 infrared spectrometer. The X-ray photoelectron spectroscopy (XPS) was characterized on a Perkin-Elmer PHI 5000C ECSA instrument. Fluorescence spectroscopy was measured by a PTI QM 40 spectrometer with excitation wavelength of $278 \mathrm{~nm}$. Circular dichroism (CD) was operated on a Bio-Logic MOS-450 spectrometer. Inductively coupled Plasma-atomic emission spectroscopy (ICP-AES) was performed on Hitachi P-4010.

\section{Results and discussion}

\subsection{Structure and morphology}

The XRD analysis of the products obtained under different conditions was shown in Fig. 1. For BSA, there was a characteristic peak of organics at around $22^{\circ}$ (Fig. 1a). The observed characteristic peak indicated the existence of BSA when the reaction time was $1 \mathrm{~min}$ (Fig. 1b). And three diffraction peaks at $36.7^{\circ}, 42.4^{\circ}$ and $62.2^{\circ}$ appeared

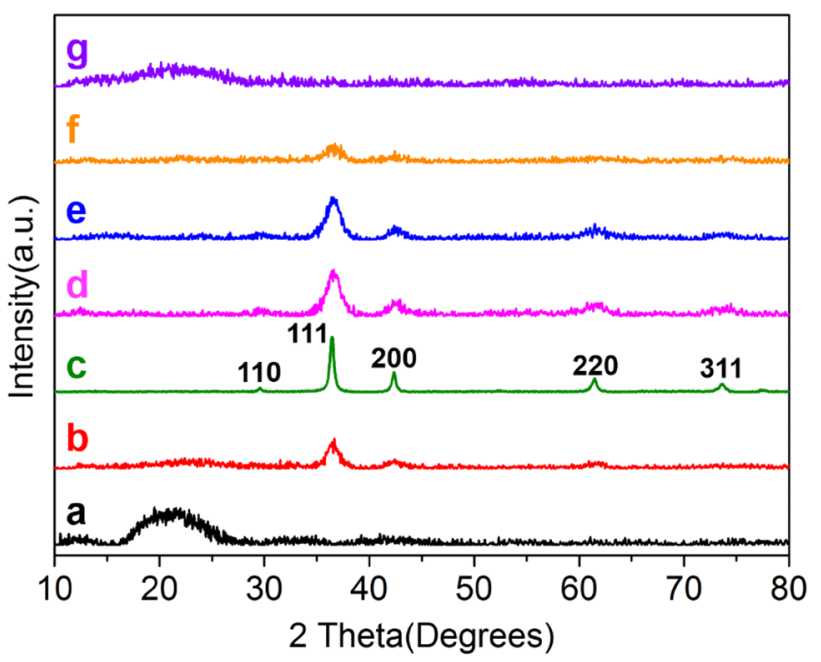

Fig. 1 XRD patterns of BSA and $\mathrm{Cu}_{2} \mathrm{O} / \mathrm{BSA}$ NCPs samples obtained under different conditions: (a) $\mathrm{BSA}$, (b) $\mathrm{BSA}-\mathrm{Cu}_{2} \mathrm{O}-1$, (c) $\mathrm{BSA}-0$ $\mathrm{Cu}_{2} \mathrm{O}$, (d) BSA-0.1- $\mathrm{Cu}_{2} \mathrm{O}$, (e) $\mathrm{BSA}-\mathrm{Cu}_{2} \mathrm{O}$, (f) $\mathrm{BSA}-0.3-\mathrm{Cu}_{2} \mathrm{O}$, (g) BSA$0.4-\mathrm{Cu}_{2} \mathrm{O}$

in Fig. $1 \mathrm{~b}$ which matched $\mathrm{Cu}_{2} \mathrm{O}$ (JCPDS 65-3288) and represented (111), (200) and (220) planes of $\mathrm{Cu}_{2} \mathrm{O}$. It suggested that $\mathrm{Cu}_{2} \mathrm{O}$ could be synthesized rapidly. The intensity of diffraction peaks (Fig. 1e) gradually increased as the reaction time prolonged, implying the increase of crystallinity degree. The samples with different content of BSA were compared when the reaction time reached $1 \mathrm{~h}$. Five obvious diffraction peaks were found in $\mathrm{BSA}-0-\mathrm{Cu}_{2} \mathrm{O}$ (Fig. 1c) and the marked diffraction peaks all matched $\mathrm{Cu}_{2} \mathrm{O}$ (JCPDS 65-3288). The average grain size was $36 \mathrm{~nm}$ according to the calculation of the XRD results. $\mathrm{BSA}-0.1-\mathrm{Cu}_{2} \mathrm{O}$ (Fig. 1d) and $\mathrm{BSA}-\mathrm{Cu}_{2} \mathrm{O}$ (Fig. 1e) also showed five diffraction peaks of $\mathrm{Cu}_{2} \mathrm{O}$ without other impurities, but the peak width was larger, indicating the smaller grain size. The average grain sizes were 4.0 and $6.4 \mathrm{~nm}$, respectively. This demonstrated that the addition of BSA could reduce the grain size of $\mathrm{Cu}_{2} \mathrm{O}$ significantly. The intensities of $\mathrm{Cu}_{2} \mathrm{O}$ diffraction peak decreased as the content of BSA further increased. Only two diffraction peaks of $\mathrm{Cu}_{2} \mathrm{O}$ could be observed in BSA$0.3-\mathrm{Cu}_{2} \mathrm{O}$ (Fig. 1f) and only the peak of BSA could be seen when the BSA increased to $0.4 \mathrm{~g}$ (Fig. 1 $\mathrm{g}$ ), indicating that excessive BSA might reduce the content of $\mathrm{Cu}_{2} \mathrm{O}$ and make the formation of $\mathrm{Cu}_{2} \mathrm{O}$ tougher. Therefore, the addition of $\mathrm{BSA}$ was better to be controlled in the range of $0.1-0.2 \mathrm{~g}$.

To investigate the composition of the $\mathrm{Cu}_{2} \mathrm{O} / \mathrm{BSA}$ hierarchical structure, the element contents of the sample $\mathrm{BSA}-\mathrm{Cu}_{2} \mathrm{O}$ and pure BSA were compared by EDX and XPS (Table 2). The main components of BSA are $\mathrm{C}, \mathrm{N}, \mathrm{O}, \mathrm{P}, \mathrm{S}$, and $\mathrm{Cu}_{2} \mathrm{O}$ includes element $\mathrm{Cu}$ and $\mathrm{O}$. Both results showed that $\mathrm{BSA}-\mathrm{Cu}_{2} \mathrm{O}$ also contained $\mathrm{C}, \mathrm{N}, \mathrm{P}$ and $\mathrm{S}$ elements besides $\mathrm{Cu}$ and $\mathrm{O}$ elements, which suggested that $\mathrm{BSA}-\mathrm{Cu}_{2} \mathrm{O}$ contained a large number of organics. The proportions of 
Table 2 EDX and XPS element contents (at\%) of BSA and $\mathrm{BSA}-\mathrm{Cu}_{2} \mathrm{O}$

\begin{tabular}{llllllll}
\hline $\begin{array}{l}\text { Characteriza- } \\
\text { tion }\end{array}$ & Sample & $\mathrm{C}$ & $\mathrm{N}$ & $\mathrm{O}$ & $\mathrm{P}$ & $\mathrm{S}$ & $\mathrm{Cu}$ \\
\hline EDX & $\mathrm{BSA}$ & 71.64 & 11.91 & 15.61 & 0.03 & 0.82 & 0 \\
& $\mathrm{BSA}-\mathrm{Cu}_{2} \mathrm{O}$ & 62.70 & 7.69 & 14.02 & 0.02 & 0.43 & 15.14 \\
$\mathrm{XPS}$ & $\mathrm{BSA}$ & 70.07 & 9.95 & 19.29 & 0.08 & 0.61 & 0 \\
& $\mathrm{BSA}-\mathrm{Cu}_{2} \mathrm{O}$ & 68.45 & 7.73 & 22.07 & 0.10 & 0.51 & 1.41 \\
\hline
\end{tabular}

elements in $\mathrm{BSA}-\mathrm{Cu}_{2} \mathrm{O}$ were similar with pure BSA. Thus, $\mathrm{BSA}-\mathrm{Cu}_{2} \mathrm{O}$ was composite materials, which contained both $\mathrm{BSA}$ and $\mathrm{Cu}_{2} \mathrm{O}$. In addition, the contents of $\mathrm{Cu}$ tested by two kinds of characterization methods were quite different. EDX can measure the elements of bulks and the testing depth reaches micron level, while XPS can only test the element contents of surface and the depth is nanoscale. Therefore, it proved that the $\mathrm{Cu}_{2} \mathrm{O}$ was more likely to locate in the internal of samples and BSA tended to distribute on the surface of samples, suggested that Cu2O and BSA dispersed from each other in the hierarchical structure.

Figure 2 presented the morphology of samples obtained under different conditions. There were many nanoparticles with the particle size of 20 to $50 \mathrm{~nm}$ in $\mathrm{Cu}_{2} \mathrm{O}$ without BSA (Fig. 2a), while the sample had no porous structure. Figure $2 \mathrm{~b}$ showed the morphology of $\mathrm{BSA}-\mathrm{Cu}_{2} \mathrm{O}-1$. Many nanocomposite particles with porous structure and particle size of 20 to $50 \mathrm{~nm}$ could be observed. These NCPs were surrounded by organic films. The TEM images of $\mathrm{Cu}_{2} \mathrm{O} / \mathrm{BSA} \mathrm{NCPs}$ obtained with different reaction time are shown in Fig. S1. The homogeneity and dispersibility of $\mathrm{Cu}_{2} \mathrm{O} / \mathrm{BSA}$ NCPs are getting better as time increases. Combined with the XRD results, it illustrated that the $\mathrm{Cu}_{2} \mathrm{O}$ formed rapidly and the specific morphology of $\mathrm{Cu}_{2} \mathrm{O} / \mathrm{BSA}$ NCPs formed after only $1 \mathrm{~min}$. The morphology stabilized after reacting $1 \mathrm{~h}$, so $1 \mathrm{~h}$ was chosen to be the reaction time. The morphology of samples prepared by adding different contents of BSA was different. The particle size was similar but porous structures appeared when adding $0.1 \mathrm{~g} \mathrm{BSA}$ (Fig. 2c). And there was a slight agglomeration between nanoparticles. When the addition of BSA increased to $0.2 \mathrm{~g}$ (Fig. $2 \mathrm{~d}$ ), the morphology of the nanocomposites was similar with that of BSA-0.1- $\mathrm{Cu}_{2} \mathrm{O}$. However, $\mathrm{BSA}-\mathrm{Cu}_{2} \mathrm{O}$ had better dispersion
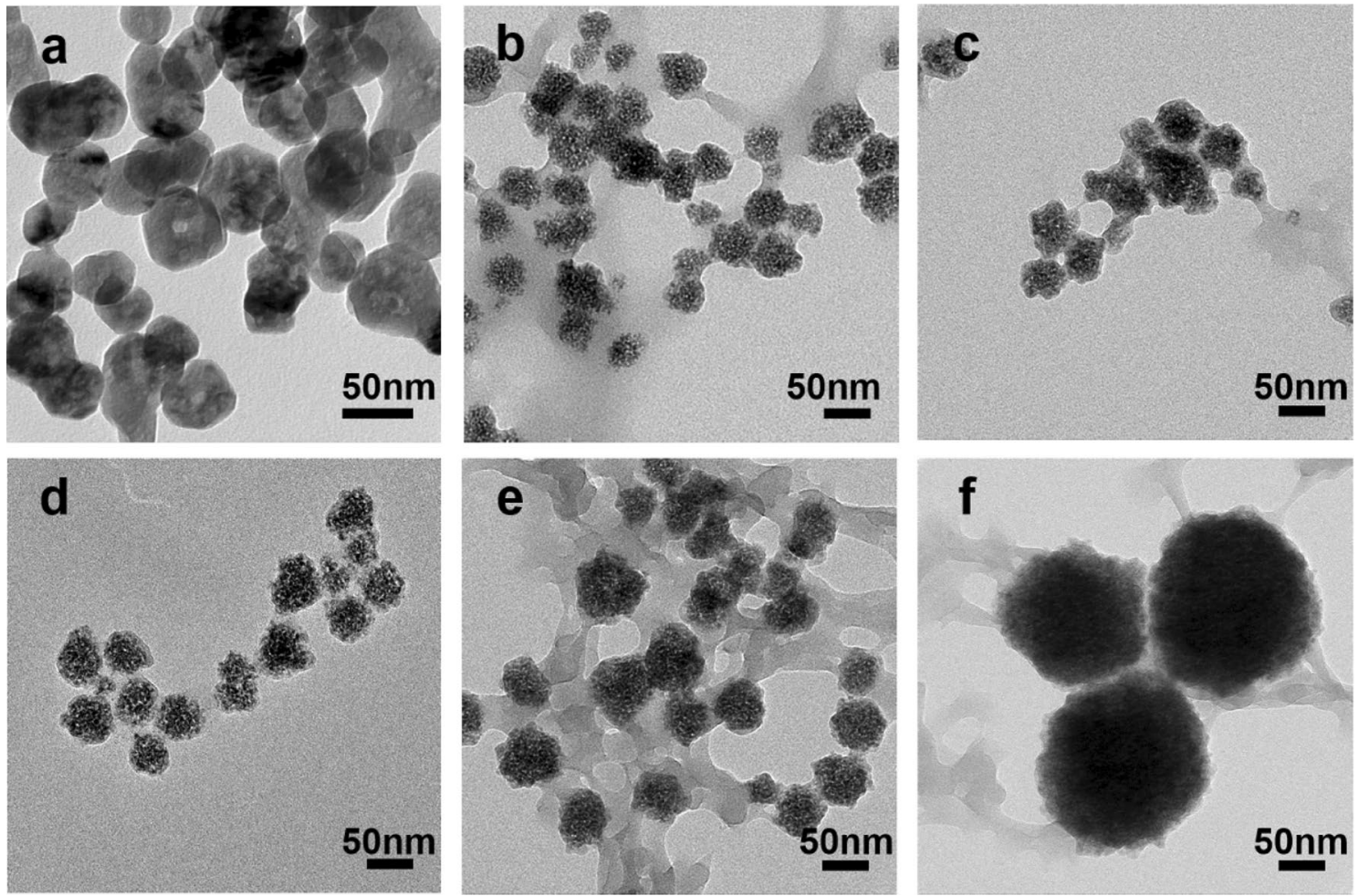

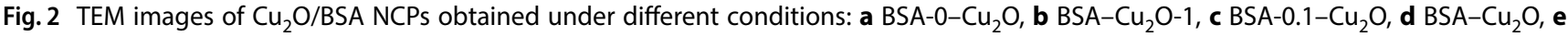
BSA-0.3- $\mathrm{Cu}_{2} \mathrm{O}, \mathrm{f}$ BSA-0.4- $\mathrm{Cu}_{2} \mathrm{O}$

\section{SN Applied Sciences}


and less aggregation. Lots of organic films were observed when BSA increased to $0.3 \mathrm{~g}$ (Fig. 2e). In this sample, the porous structure was still reserved, but the particle size was slightly larger than that of $\mathrm{BSA}-\mathrm{Cu}_{2} \mathrm{O}$. When the $\mathrm{BSA}$ content increased to $0.4 \mathrm{~g}$ (Fig. $2 \mathrm{f}$ ), besides the more organic films, the particle size exceeded $100 \mathrm{~nm}$ and the porous structure disappeared. Unlike BSA-0- $\mathrm{Cu}_{2} \mathrm{O}, \mathrm{BSA}-$ $0.4-\mathrm{Cu}_{2} \mathrm{O}$ had rough surface. The figure showed the existence of $\mathrm{Cu}_{2} \mathrm{O}$ in this scale, but the overall content was quite low. Actually, most of the samples were organic films which were consistent with the XRD results. Thus, the content of BSA was determined to be $0.2 \mathrm{~g}$.

The structures of $\mathrm{BSA}-\mathrm{Cu}_{2} \mathrm{O}$ were analyzed by HRTEM as shown in Fig. 3. Figure 3 a showed the structure of the sample $\mathrm{BSA}-\mathrm{Cu}_{2} \mathrm{O}: \mathrm{Cu}_{2} \mathrm{O}$ crystals were mixed with organics (BSA), which was consistent with the results of EDX and XPS. Figure $3 \mathrm{~b}$ exhibited the structure of single $\mathrm{BSA}-\mathrm{Cu}_{2} \mathrm{O}$ nanoparticle. It could be seen that the nanoparticle was assembled by several smaller sub-nanocrystals. Figure $3 \mathrm{c}$ showed the HRTEM image of single BSA- $\mathrm{Cu}_{2} \mathrm{O}$ nanoparticle. There were several lattice fringes in different directions indicating the existence of the polycrystalline structure. So nanocomposite could be divided into small sub-nanocrystal, based on the lattice fringe direction and contrast of images, as shown in white dotted line circle of Fig. 3c. It seemed that the nanocrystal size was about $7 \mathrm{~nm}$, which was consistent with the XRD calculation. And the spacing between adjacent lattice planes was about $0.25 \mathrm{~nm}$, which corresponded to the distance of $\mathrm{Cu}_{2} \mathrm{O}$ (111) planes. Figure $3 \mathrm{~d}$ presented the SAED pattern of $\mathrm{BSA}-\mathrm{Cu}_{2} \mathrm{O}$ nanoparticles. There were five diffraction rings, corresponded to the (110), (111), (200), (220) and (311) crystal planes of $\mathrm{Cu}_{2} \mathrm{O}$. There were no other diffraction rings, suggesting that $\mathrm{BSA}-\mathrm{Cu}_{2} \mathrm{O}$ contained only $\mathrm{Cu}_{2} \mathrm{O}$, but no other impurities such as $\mathrm{Cu}$ and $\mathrm{CuO}$.

\subsection{Mechanism analysis}

The FTIR spectra of different samples were shown in Fig. 4. For pure BSA (Fig. 4a), a broad band attributed to the stretching vibration of $\mathrm{O}-\mathrm{H}$ and $\mathrm{N}-\mathrm{H}$ groups appeared at around $3306 \mathrm{~cm}^{-1}$. The stretching vibration of $\mathrm{C}=\mathrm{O}$ was at $1657 \mathrm{~cm}^{-1}$. The characteristic band at $1541 \mathrm{~cm}^{-1}$ was assigned to the stretching vibration of $\mathrm{C}-\mathrm{N}$ and bending vibration of $\mathrm{N}-\mathrm{H}$ [27]. The band of $1395 \mathrm{~cm}^{-1}$ belonged to the bending vibration of $\mathrm{C}-\mathrm{H}$. Figure $4 \mathrm{e}$ showed the FTIR spectrum of commercial $\mathrm{Cu}_{2} \mathrm{O}$. There was only one band at $629 \mathrm{~cm}^{-1}$ that was corresponded to the $\mathrm{Cu}-\mathrm{O}$ group. The band of $\mathrm{Cu}-\mathrm{O}$ had appeared when the reaction time was 1 min (Fig. 4b), indicating the existence of $\mathrm{Cu}_{2} \mathrm{O}$. Compared
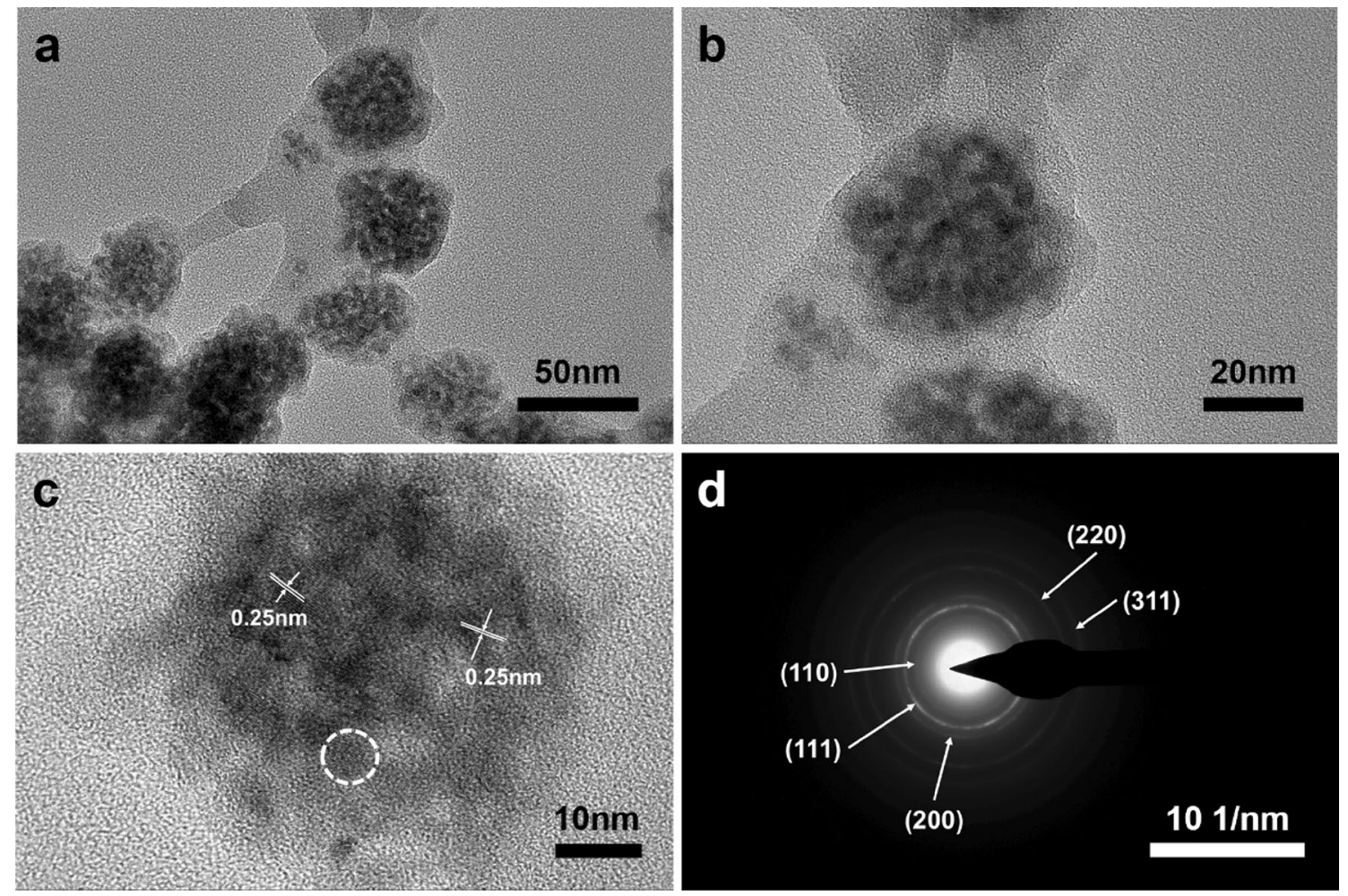

Fig. 3 a TEM image of the sample $\mathrm{BSA}-\mathrm{Cu}_{2} \mathrm{O}$, b TEM image of the single $\mathrm{BSA}-\mathrm{Cu}_{2} \mathrm{O}$ nanoparticle, $\mathbf{c} \mathrm{HRTEM}$ lattice image of $\mathrm{BSA}-\mathrm{Cu} \mathrm{O}_{2} \mathrm{O}$ nanoparticles, $\mathbf{d}$ the SAED pattern of $\mathbf{b}$. One single nanocrystal is within a white dotted line circle 


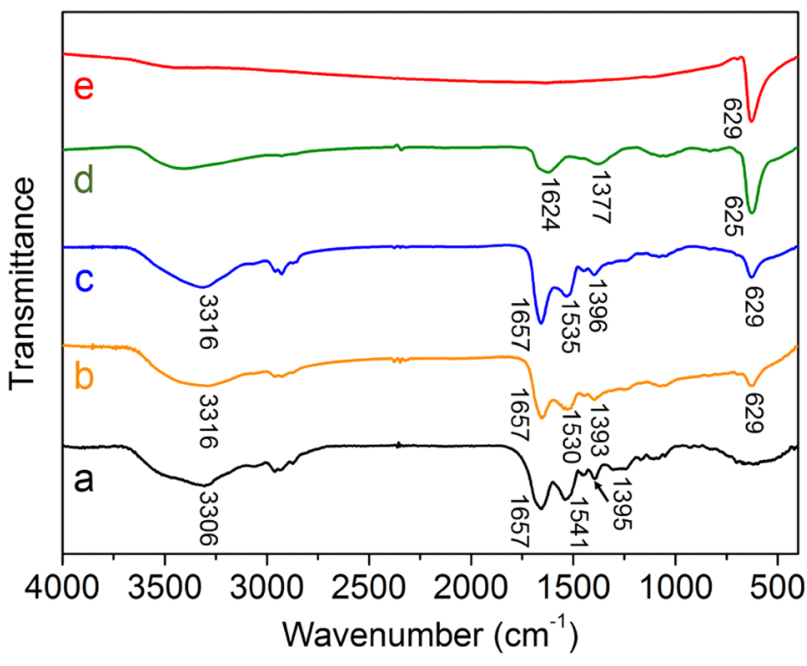

Fig. 4 FTIR spectra of: (a) BSA, (b) $\mathrm{BSA}-\mathrm{Cu}_{2} \mathrm{O}-1$, (c) $\mathrm{BSA}-\mathrm{Cu}_{2} \mathrm{O}$, (d) BSA-0- $\mathrm{Cu}_{2} \mathrm{O}$, (e) commercial $\mathrm{Cu}_{2} \mathrm{O}$
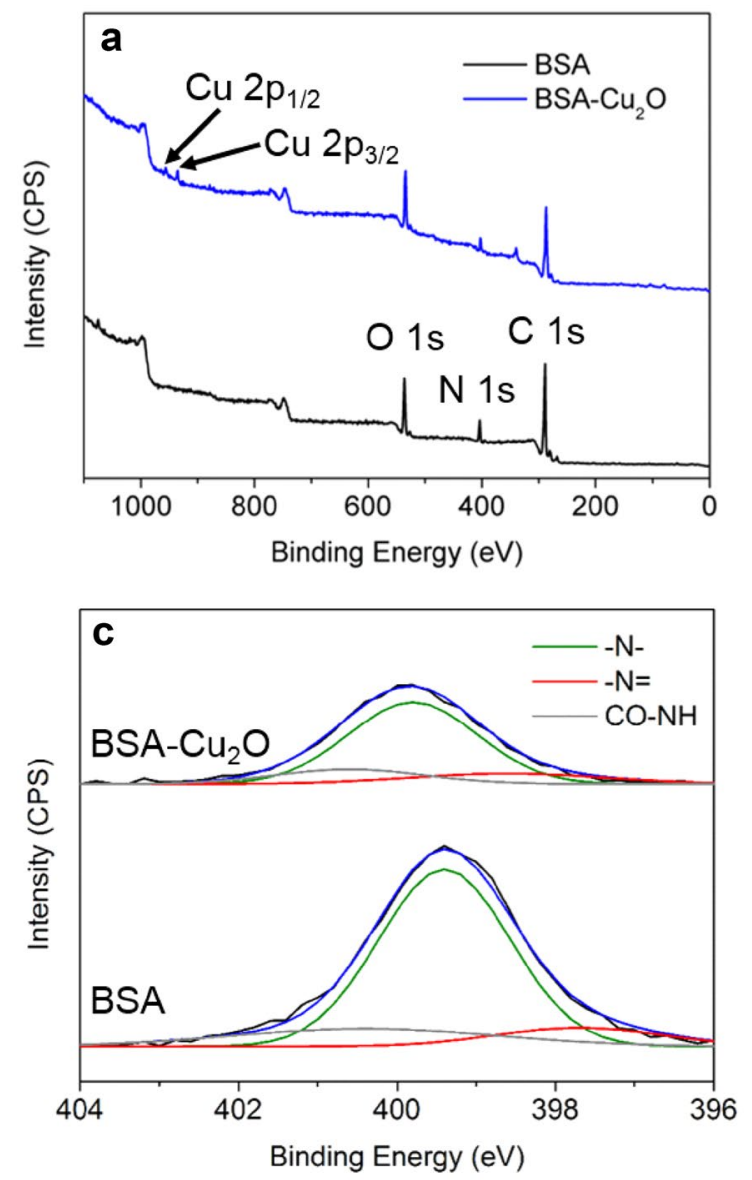

with pure BSA, the sample had all functional groups of $B S A$ suggesting that the presence of BSA. In addition, the stretching vibration of $\mathrm{C}=\mathrm{O}$ did not shift which meant the carbonyl group did not interact with $\mathrm{Cu}^{2+}$. However, the vibration band of $\mathrm{C}-\mathrm{N}$ and $\mathrm{N}-\mathrm{H}$ shifted to lower wavenumber, which was due to the coordination of $\mathrm{Cu}^{2+}$ with $\mathrm{N}$ atoms. The FTIR spectrum of $\mathrm{BSA}-\mathrm{Cu}_{2} \mathrm{O}$ (Fig. $4 \mathrm{C}$ ) was similar with that of $\mathrm{BSA}-\mathrm{Cu}_{2} \mathrm{O}-1$. There were also some organic functional groups besides the $\mathrm{Cu}-\mathrm{O}$ bond in $\mathrm{BSA}-\mathrm{O}-\mathrm{Cu}_{2} \mathrm{O}$ (Fig. 4d). This might be owing to some groups of residual ascorbic acid.

Pure BSA and $\mathrm{BSA}-\mathrm{Cu}_{2} \mathrm{O}$ were tested by XPS to explore the coordination of functional groups with $\mathrm{Cu}^{2+}$, and the results were shown in Fig. 5. Figure 5a showed the general XPS of pure BSA and $\mathrm{BSA}-\mathrm{Cu}_{2} \mathrm{O}$. Detailed data and analysis could be seen in Table 2 .

Figure $5 \mathrm{~b}$ presented the $\mathrm{O} 1 \mathrm{~s}$ XPS of $\mathrm{BSA}$ and $\mathrm{BSA}-\mathrm{Cu}_{2} \mathrm{O}$. For pure BSA, the peaks located at 530.9 and $532.4 \mathrm{eV}$ were attributed to $\mathrm{C}=\mathrm{O}$ and $\mathrm{O}-\mathrm{H}$ bonds, respectively [27]. For $\mathrm{BSA}-\mathrm{Cu}_{2} \mathrm{O}$, these two peaks slightly shifted to 531.0 and $532.5 \mathrm{eV}$, respectively. Combined with the FTIR results,
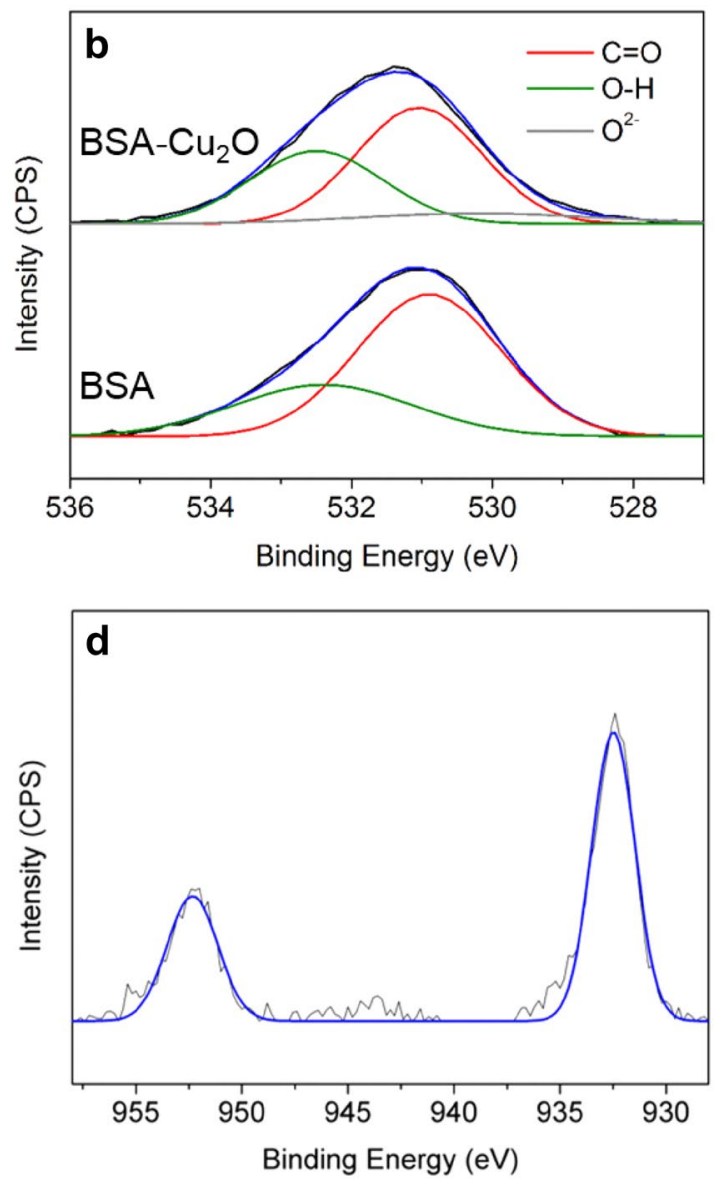

Fig. 5 a The general XPS spectra, b O $1 s$ XPS spectra, $\mathbf{c} N$ 1s XPS spectra of the samples BSA and BSA-Cu $\mathrm{O}_{2} \mathbf{d}$ Cu $2 p$ XPS spectra of the sample $\mathrm{BSA}-\mathrm{Cu}_{2} \mathrm{O}$ 
$\mathrm{C}=\mathrm{O}$ and $\mathrm{O}-\mathrm{H}$ might have coordination with $\mathrm{Cu}^{2+}$, but the bond was weak compared to other groups. Besides, a new peak at $530.2 \mathrm{eV}$ appeared corresponding to the $\mathrm{O}^{2-}$ ions in the $\mathrm{Cu}_{2} \mathrm{O}$ lattice, indicating the formation of $\mathrm{Cu}_{2} \mathrm{O}$ [28].

Figure $5 \mathrm{c}$ presented the $\mathrm{N} 1 s$ XPS of $\mathrm{BSA}$ and $\mathrm{BSA}-\mathrm{Cu}_{2} \mathrm{O}$. For pure BSA, the peaks located at 397.7, 399.4 and $400.4 \mathrm{eV}$ were due to imine, amine and amide bonds, respectively [29]. For $\mathrm{BSA}-\mathrm{Cu}_{2} \mathrm{O}$, the intensity of $\mathrm{N} 1 \mathrm{~s}$ reduced and the three peaks shifted to $398.6,399.8$ and $400.6 \mathrm{eV}$, respectively, indicating that the electron density of $\mathrm{N}$ atoms was less than that in BSA. It illustrated that $\mathrm{N}$ atoms all had coordination with $\mathrm{Cu}$ ions, which was consistent with the FTIR results. The imine bond shifted the most. Histidine has imine bond among amino acids, which indicated that $\mathrm{N}$ atoms of the histidine residues in BSA had stronger coordination with $\mathrm{Cu}^{2+}$. And lysine, arginine and tryptophan have amine bond on the side chains, implying that $\mathrm{N}$ atoms of these residues participated in the coordination. Glutamine and asparagine have amide structures. Since the shift was small, the coordination of these residues was relatively weak.

Figure $5 d$ presented the $\mathrm{Cu} 2 p$ XPS of BSA and $\mathrm{BSA}-\mathrm{Cu}_{2} \mathrm{O}$. The peaks located at 932.5 and $952.3 \mathrm{eV}$ were due to $\mathrm{Cu} 2 p_{3 / 2}$ and $\mathrm{Cu} 2 p_{1 / 2}$, respectively [30]. No other $\mathrm{Cu} 2 p$ peaks were observed, indicating that there were no other impurities, such as $\mathrm{Cu}$ or $\mathrm{CuO}$.

Pure BSA has a large fluorescence peak at $300-460 \mathrm{~nm}$, indicating the intact structure of the fluorescent group such as tryptophan in $\mathrm{BSA}$. In the sample $\mathrm{BSA}-\mathrm{Cu}_{2} \mathrm{O}$, the fluorescence peak disappears completely and fluorescence quenching occurred, for that these fluorophorecontaining amino acid residues coordinate with $\mathrm{Cu}^{2+}$, and the fluorescence intensity is greatly reduced to zero. In our research, the binding of the groups in BSA to $\mathrm{Cu}^{2+}$ is investigated through observing the change of the peak at $300-460 \mathrm{~nm}$. Circular dichroism spectra (CD) are widely applied to determine the secondary structure of protein for studying the conformation of proteins. CD spectra were used to investigate the structural changes of BSA before and after the reaction, to support the formation mechanism of $\mathrm{Cu}_{2} \mathrm{O} / \mathrm{BSA} \mathrm{NCPs}$. To explore the changes of BSA during the reaction, the fluorescence and $C D$ spectra of the samples BSA and BSA-Cu $\mathrm{Cu}_{2} \mathrm{O}$ were shown in Fig. 6.

Figure $6 \mathrm{a}$ exhibited the fluorescence spectra of the two samples excited at $278 \mathrm{~nm}$ [31]. BSA had a significant fluorescence due to the tryptophan residues [31]. For $\mathrm{BSA}-\mathrm{Cu}_{2} \mathrm{O}$, the fluorescence was quenched, indicating the destruction of the residues. Combined with the XPS results, it demonstrated the coordination of indole amine in tryptophan residues with $\mathrm{Cu}^{2+}$. Figure $6 \mathrm{~b}$ showed the $\mathrm{CD}$ spectra of $\mathrm{BSA}$ and $\mathrm{BSA}-\mathrm{Cu}_{2} \mathrm{O}$. For pure BSA, there was a band at $222 \mathrm{~nm}$ which was the characteristic transition of a-helical structure of BSA [32]. However, the negative band of $\mathrm{BSA}-\mathrm{Cu}_{2} \mathrm{O}$ completely disappeared. It was the coordination of $\mathrm{Cu}^{2+}$ and $\mathrm{BSA}$ that broke the hydrogen bond which was located in the a-helical structure and destroyed the secondary structure of BSA. Finally, the chains of the a-helical region were stretched.

Based on the investigations and results above, a possible formation mechanism of $\mathrm{Cu}_{2} \mathrm{O} / \mathrm{BSA} \mathrm{NCPs}$ is presented in Fig. 7. Figure 7a showed the structure of BSA. Based on the results above, the tryptophan and histidine residues had stronger coordination with $\mathrm{Cu}^{2+}$ while that of the other functional groups on side chain was weaker. Thus, the former was the major consideration on the formation mechanism. One BSA molecule has 2 tryptophan residues and 17 histidine residues [33]. The locations of one tryptophan and one histidine residues were marked in the Fig. 7a. Theoretically, they could all coordinate with $\mathrm{Cu}^{2+}$. However, there was a strong binding site at the $\mathrm{N}$-terminal tetrapeptide (Asp-Thr-His-Lys) and $\mathrm{Cu}^{2+}$ would first coordinate with this binding site [34]. This step
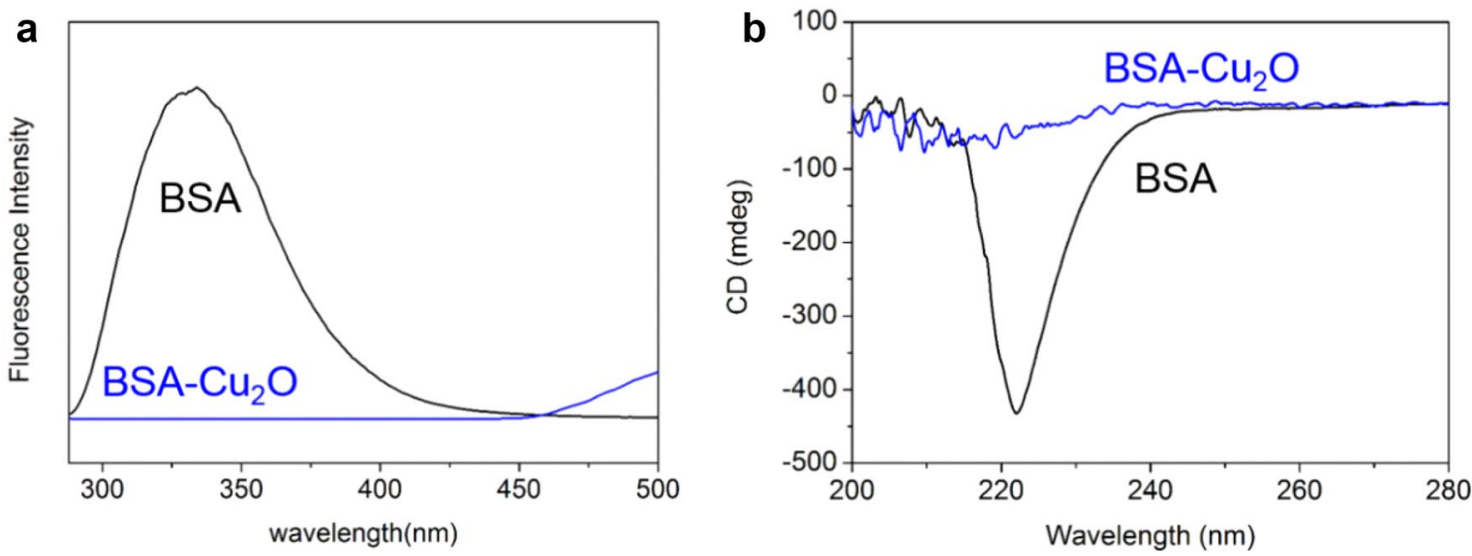

Fig. 6 a Fluorescence spectra of the two samples excited at $278 \mathrm{~nm}, \mathbf{b} \mathrm{CD}$ spectra of the samples BSA and BSA-Cu 


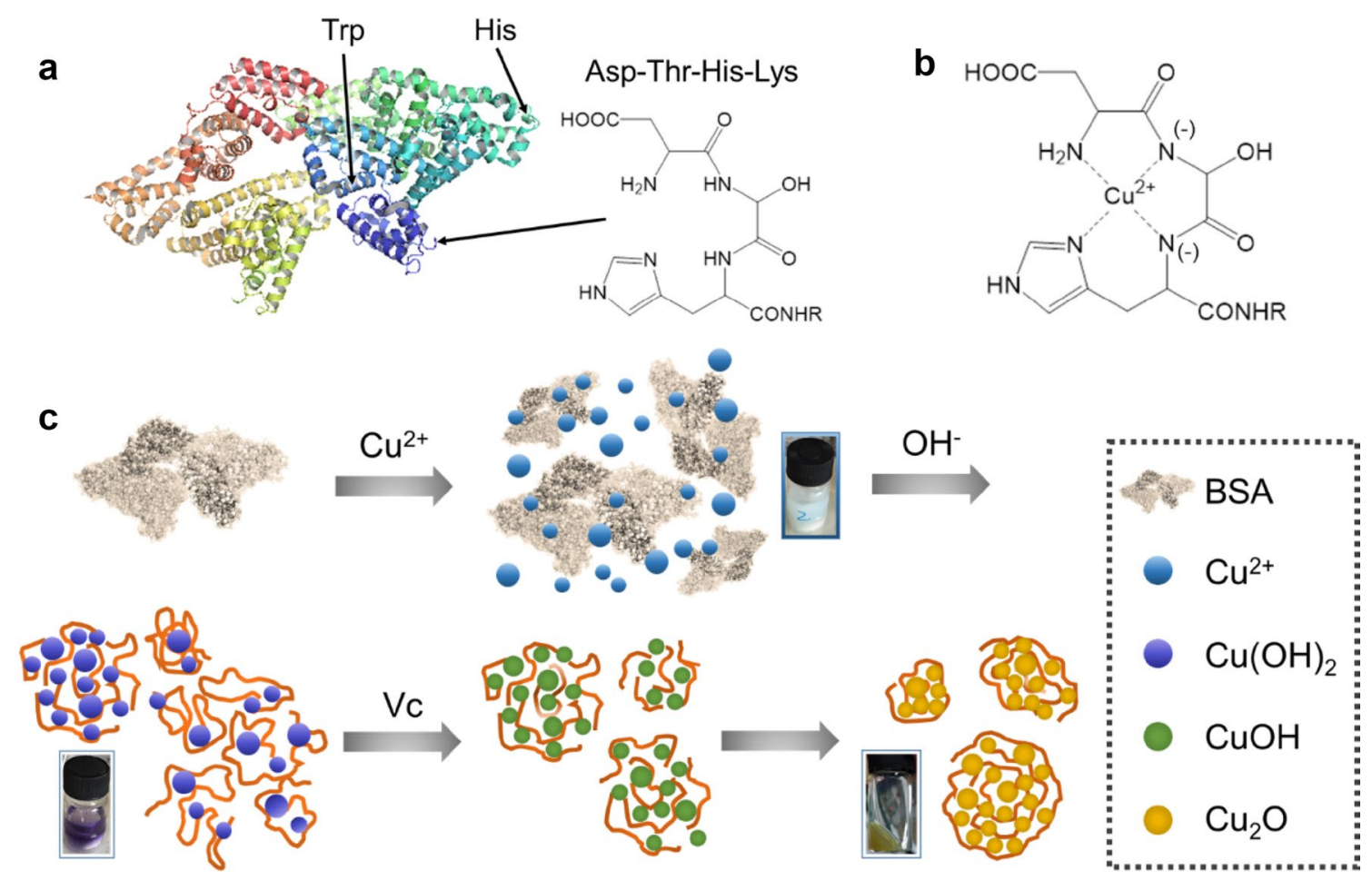

Fig. 7 Schematic illustration of $\mathrm{Cu}_{2} \mathrm{O} / \mathrm{BSA}$ NCPs formation process: $\mathbf{a}$ the structure of BSA, $\mathbf{b}$ N-terminal of $\mathrm{BSA}$ binding with $\mathrm{Cu}^{2+}$, $\mathbf{c}$ formation illustration of the $\mathrm{Cu}_{2} \mathrm{O} / \mathrm{BSA}$ NCPs

was difficult, but after the first coordination with $\mathrm{Cu}^{2+}$, the conformation of BSA changed. The allosteric effect could inhibit the $\mathrm{Cu}^{2+}$-induced cross-linking of BSA and exposed more binding sites [34]. These both promoted the next coordination of other sites with $\mathrm{Cu}^{2+}$. Figure $7 \mathrm{~b}$ showed the coordination structure of $\mathrm{Cu}^{2+}$ and Asp-Thr-His-Lys under alkaline conditions [35]. The characteristic square planar $\mathrm{Cu}^{2+}$ coordinated with the deprotonated amide of Thr and His, amine of Asp and imidazole of His. The reaction was similar with the biuret reaction and the purple $\mathrm{Cu}$ complex was formed.

Figure $7 \mathrm{c}$ was the formation illustration of $\mathrm{Cu}_{2} \mathrm{O} / \mathrm{BSA}$ NCPs. $\mathrm{Cu}^{2+}$ first coordinated with N-terminal of BSA and changed the protein conformation. Then, the rest of $\mathrm{Cu}^{2+}$ could further coordinate with other histidine and tryptophan residues, resulting in the denaturation of BSA and formation of white floc (Figs. S2a and S2d). The N-terminal Cu complex was formed (Fig. 7b) and the solution turned purple after the addition of $\mathrm{NaOH}$. The local concentration of $\mathrm{Cu}^{2+}$ at binding sites was quite high, for that the precipitation provided surfaces, which were more likely to adsorb metal ions. Therefore, it was favorable for the extremely rapid reaction of $\mathrm{Cu}^{2+}$ with $\mathrm{OH}^{-}$to generate small $\mathrm{Cu}(\mathrm{OH})_{2}$ precipitates (Fig. S2b). These $\mathrm{Cu}(\mathrm{OH})_{2}$ could grow along the peptide chain of BSA and the structure of BSA changed to porous structure (Fig. S2e). There was certain steric effect around $\mathrm{Cu}(\mathrm{OH})_{2}$ precipitates because of the interspaces between sites and sites and the existence of other amino acid residues and peptide chains. Therefore, the aggregation of $\mathrm{Cu}(\mathrm{OH})_{2}$ was limited and the particle size was controlled in several nanometers. And then the $\mathrm{Cu}(\mathrm{OH})_{2}$ precipitates at the binding sites and BSA assembled together to form a hierarchical structure. BSA was used as the structure-directing agent to guide the nucleation, growth and assembly $\mathrm{Cu}(\mathrm{OH})_{2}$. After ascorbic acid added, the $\mathrm{Cu}(\mathrm{OH})_{2}$ was reduced to $\mathrm{CuOH}$ and decomposed into yellow $\mathrm{Cu}_{2} \mathrm{O}$ (Fig. S2C). Finally, $\mathrm{Cu}_{2} \mathrm{O} / \mathrm{BSA}$ NCPs composed of several $\mathrm{Cu}_{2} \mathrm{O}$ nanocrystals and $\mathrm{BSA}$ were obtained (Fig. S2f).

The whole reaction was very fast and the reaction progress could be judged by the color change. The relative contents of $\mathrm{Cu}^{2+}$ and $\mathrm{BSA}$ was very important owing to the coordination priority and order as discussed above. $\mathrm{Cu}^{2+}$ was not enough for the conformational changes of all the BSA if too much BSA (e.g. $0.4 \mathrm{~g}$ ) was added. $\mathrm{Cu}^{2+}$ could only react with $\mathrm{N}$-terminal of $\mathrm{BSA}$. Moreover, the high protein concentration would hinder the uniform distribution of $\mathrm{Cu}^{2+}$. The a-helical structure would not expand to provide redundant sites, so the steric effect lacked during the formation of $\mathrm{Cu}(\mathrm{OH})_{2}$. Therefore, $\mathrm{Cu}(\mathrm{OH})_{2}$ precipitation was easy to aggregate to form large particles. And numerous $\mathrm{Cu}^{2+}$ would be concentrated at $\mathrm{N}$-terminal binding sites, leading to the rapid generation of large amounts of $\mathrm{Cu}(\mathrm{OH})_{2}$ precipitation. Thus, the particle size was even 
larger than that of the $\mathrm{Cu}_{2} \mathrm{O}$ produced without $\mathrm{BSA}$. The obstruction of protein among the $\mathrm{Cu}_{2} \mathrm{O}$ particles was insufficient when the content of BSA was low, so there would be a slight agglomeration.

\subsection{Antibacterial performance}

Preliminary antibacterial tests against $S$. aureus of BSA0.1- $\mathrm{Cu}_{2} \mathrm{O}, \mathrm{BSA}-\mathrm{Cu}_{2} \mathrm{O}, \mathrm{BSA}-0.3-\mathrm{Cu}_{2} \mathrm{O}$ and BSA-0.4- $\mathrm{Cu}_{2} \mathrm{O}$ were carried out. The corresponding antibacterial ratio were $95 \%, 100 \%, 98 \%$ and $88 \%$, respectively. Therefore, $\mathrm{BSA}-\mathrm{Cu}_{2} \mathrm{O}$ was selected in the following antimicrobial experiments.

To study the antibacterial properties of $\mathrm{BSA}-\mathrm{Cu}_{2} \mathrm{O}, \mathrm{S}$. aureus (gram-positive bacteria) and $E$. coli (gram-negative bacteria) were selected as experimental objects. The antibacterial effect was measured after 60 min reaction and compared with BSA-0- $\mathrm{Cu}_{2} \mathrm{O}$, commercial $\mathrm{Cu}_{2} \mathrm{O}$ and $\mathrm{CuCl}$ (Fig. S2). The concentration of survival bacteria of the control groups reached $10^{5} \mathrm{CFU} \mathrm{mL}{ }^{-1}$ for S. aureus (Fig. 8a). All survival amounts dropped sharply after different samples added. In $\mathrm{BSA}-\mathrm{Cu}_{2} \mathrm{O}$ and $\mathrm{CuCl}$ groups, no bacteria survive. The survival concentration of $\mathrm{BSA}-\mathrm{O}-\mathrm{Cu}_{2} \mathrm{O}$ and commercial

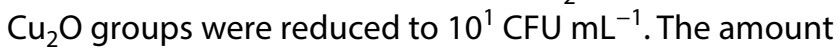
of the control groups was also up to $10^{5} \mathrm{CFU} \mathrm{mL^{-1 }}$ for $E$. coli (Fig. 8b). After different samples added, all survival amounts decreased but the overall antibacterial effect was weaker. The reason might be that thinner single-layer and negative phosphate cell wall of gram-positive bacteria made $\mathrm{Cu}^{+}$easier to permeate cell walls through electrostatic interactions. The count of commercial $\mathrm{Cu}_{2} \mathrm{O}$ group was nearly the same as that of the control group. The number of bacteria in $\mathrm{BSA}-\mathrm{O}-\mathrm{Cu}_{2} \mathrm{O}$ group only decreased one order of magnitude. $\mathrm{CuCl}$ group still had $10^{1} \mathrm{CFU} \mathrm{mL} \mathrm{m}^{-1}$ of bacteria surviving. However, there were no bacteria existing in $\mathrm{BSA}-\mathrm{Cu}_{2} \mathrm{O}$ groups. These two experiments indicated that $\mathrm{BSA}-\mathrm{Cu}_{2} \mathrm{O}$ had better antibacterial properties than the others.

The antibacterial mechanism of $\mathrm{Cu}_{2} \mathrm{O}$ is mainly by contacting cell walls to kill bacteria. There are two ways: (1) direct contact with the cell wall of bacteria and damage them, (2) releasing $\mathrm{Cu}^{+}$into solution and react with cell walls $[36,37]$. In this research, S. aureus was used as antibacterial objects to explore the antibacterial mechanism of $\mathrm{BSA}-\mathrm{Cu}_{2} \mathrm{O}$. The number of bacteria living and the release amount of copper ions of different samples in different time were investigated.

Figure 9a showed the survival amount of $S$. aureus in different time. The number of living bacteria of $\mathrm{Cu}_{2} \mathrm{O}$ group gradually decreased. The decline tend of $\mathrm{BSA}-0-\mathrm{Cu}_{2} \mathrm{O}$ group was rapid at first and then became slower. The concentration of bacteria in $\mathrm{BSA}-\mathrm{Cu}_{2} \mathrm{O}$ and $\mathrm{CuCl}$ groups decreased very fast. The $\mathrm{CuCl}$ group took $10 \mathrm{~min}$ to kill all bacteria, while the $\mathrm{BSA}-\mathrm{Cu}_{2} \mathrm{O}$ group cost only $5 \mathrm{~min}$.

Figure $9 \mathrm{~b}$ exhibited the copper release of different samples in different time. The cuprous ions of $\mathrm{CuCl}$ dissolved in solution and kept high Cu element concentration. The copper release of commercial $\mathrm{Cu}_{2} \mathrm{O}$ was slow and stable. BSA-0- $\mathrm{Cu}_{2} \mathrm{O}$ released copper rapidly at first and then slowly. The ion release of $\mathrm{BSA}-\mathrm{Cu}_{2} \mathrm{O}$ was relatively stable. In theory, the release rate should be the fastest due to the large specific surface area of the particles with small size. However, the measured concentration was slightly lower than that of BSA-0- $\mathrm{Cu}_{2} \mathrm{O}$ and commercial $\mathrm{Cu}_{2} \mathrm{O}$. This might be attributed to that $\mathrm{BSA}-\mathrm{Cu}_{2} \mathrm{O}$ contained a certain amount of $\mathrm{BSA}$, and the $\mathrm{Cu}_{2} \mathrm{O}$ content was lower than others.

By comparison, the antibacterial velocities of $\mathrm{BSA}-0-\mathrm{Cu}_{2} \mathrm{O}$, commercial $\mathrm{Cu}_{2} \mathrm{O}$ and $\mathrm{CuCl}$ were proportional to the copper release rates. The $\mathrm{Cu}$ concentration of $\mathrm{CuCl}$ was the highest, so the antibacterial rate was the fastest. The release amount of $\mathrm{BSA}-0-\mathrm{Cu}_{2} \mathrm{O}$ and commercial
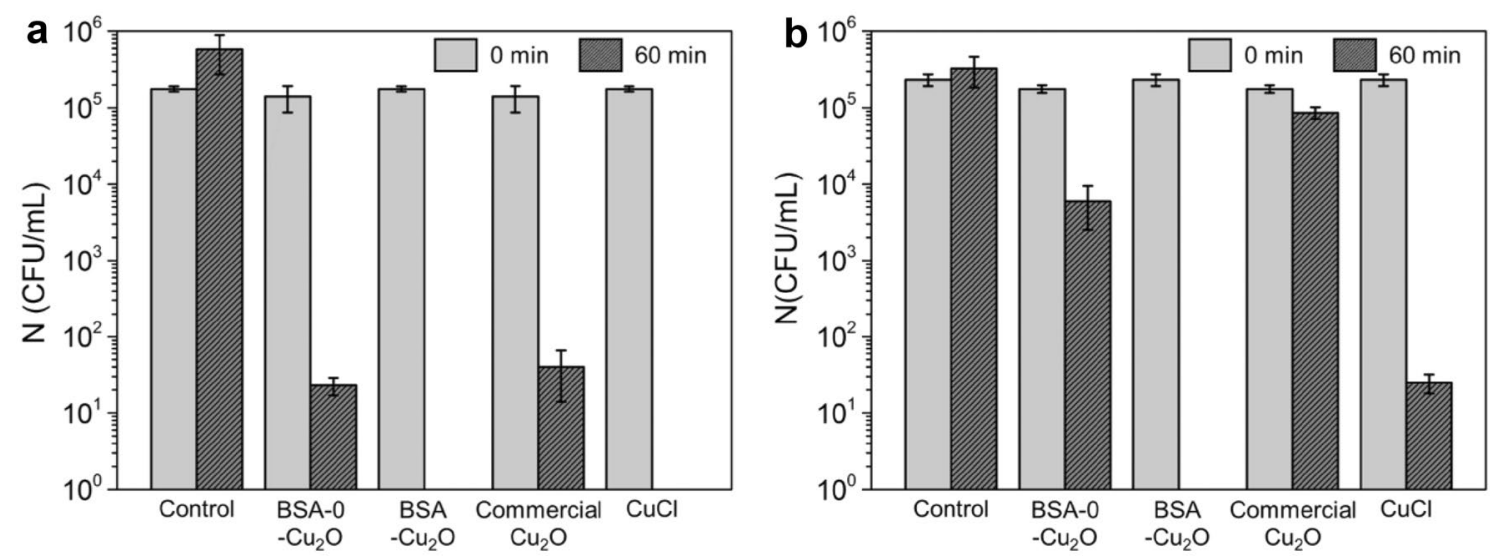

Fig. 8 Survival of a S. aureus, b E. coli by using different samples after $60 \mathrm{~min}$ of antibacterial action 

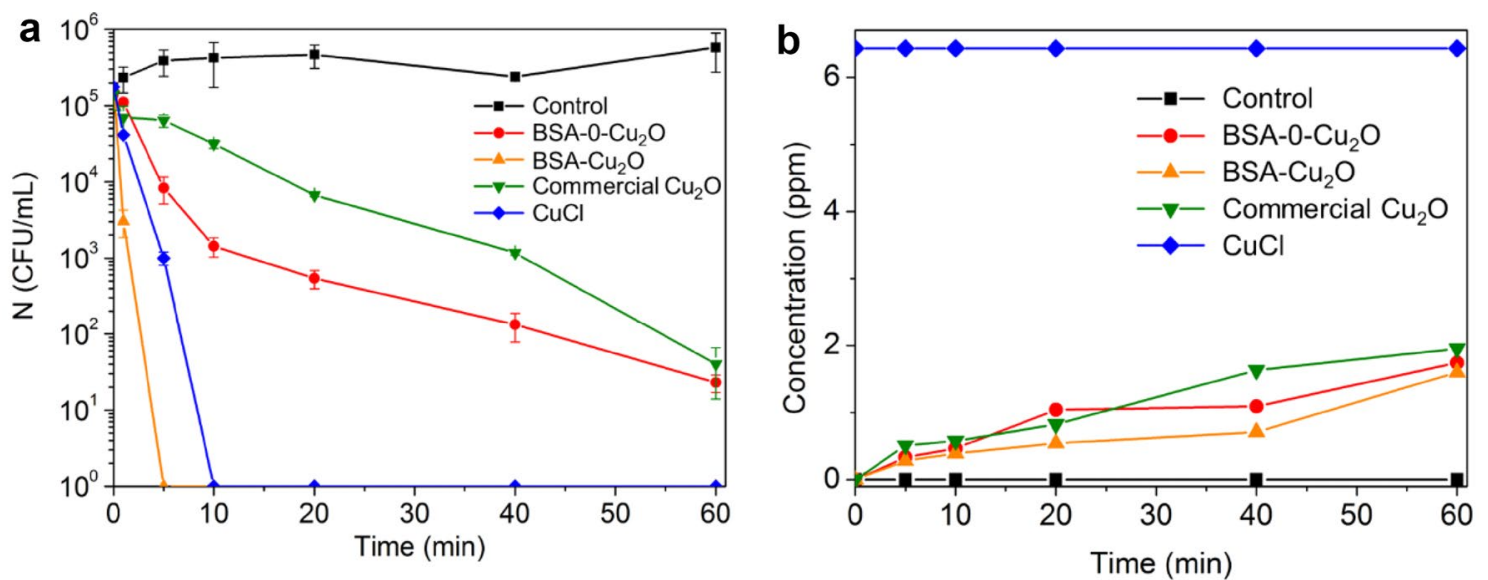

Fig. 9 a Survival of S. aureus and $\mathbf{b}$ copper release curves by using different samples in different antibacterial action time

$\mathrm{Cu}_{2} \mathrm{O}$ was similar, but the release rate was different. Figure S4 showed the FESEM images and XRD pattern of commercial $\mathrm{Cu}_{2} \mathrm{O}$. There were large numbers of nanoparticles and micro-sized particles in images indicating the particle size distribution was wide. And the narrow diffraction peaks in XRD spectra stated the particle size was quite large. However, the particle size of $\mathrm{BSA}-\mathrm{O}-\mathrm{Cu}_{2} \mathrm{O}$ was much smaller indicating the larger surface area. It could accelerate the Cu release and increase the contact probability with bacteria, so the antibacterial effect was slightly better than that of commercial $\mathrm{Cu}_{2} \mathrm{O}$. For $\mathrm{BSA}-\mathrm{Cu}_{2} \mathrm{O}$, the antibacterial effect did not completely depend on the $\mathrm{Cu}$ release rate. The release concentration of $\mathrm{Cu}$ in $\mathrm{BSA}-\mathrm{Cu}_{2} \mathrm{O}$ was much less than $\mathrm{CuCl}$, but the antibacterial rate was faster than $\mathrm{CuCl}$, which suggested that direct contact played an important role in antibacterial performance.
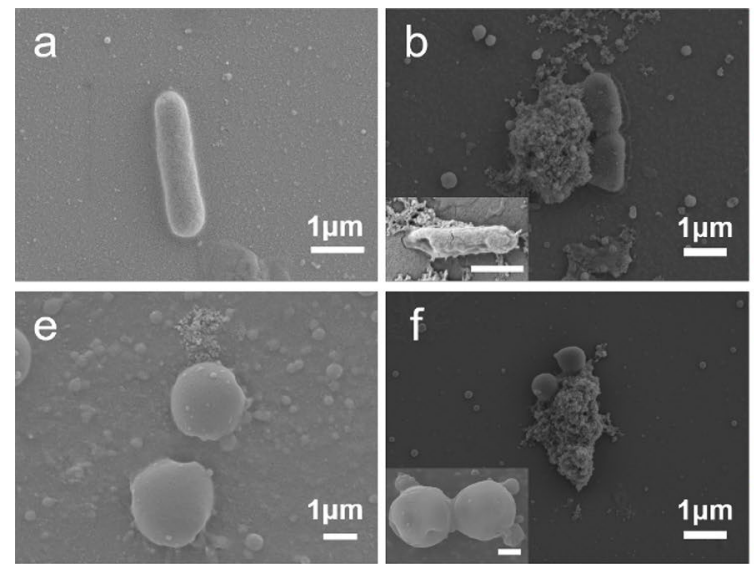

Fig. 10 Images of a $E$. coli and e S. aureus, and images of $\mathrm{BSA}-\mathrm{Cu}_{2} \mathrm{O}$ antibacterial group after $60 \mathrm{~min}$ reaction against $E$. coli (b SEM images, c elemental mapping of $\mathrm{C}$, $\mathbf{d}$ elemental mapping of $\mathrm{Cu}$ ) and
Figure 10a, e showed the morphology of E. coli and S. aureus, and Fig. 10b, $\mathrm{f}$ showed the morphology of bacteria after $\mathrm{BSA}-\mathrm{Cu}_{2} \mathrm{O}$ was added. The bacteria were surrounded by a lot of nanoparticles. And as shown in the insets, the bacteria displayed obvious deformation and the cell walls were destroyed. These both proved that $\mathrm{BSA}-\mathrm{Cu}_{2} \mathrm{O}$ $\mathrm{NCPs}$ contacted with bacteria and reacted with cell walls. According to the elemental mapping of EDX (Fig. 10c, d, $g$, $\mathrm{h})$, these nanoparticles were containing dispersed $\mathrm{Cu}$ and $\mathrm{C}$ elements. Therefore, it could be speculated that $\mathrm{BSA}$ and $\mathrm{Cu}_{2} \mathrm{O}$ were intertwined to construct the $\mathrm{BSA}-\mathrm{Cu}_{2} \mathrm{O}$ nanocomposite and various amino acid residues distributed in and on the surface of the composite. These residues had good biocompatibility, which was in favor of the direct contact between $\mathrm{BSA}-\mathrm{Cu}_{2} \mathrm{O}$ nanoparticles and bacterial cell walls, and then $\mathrm{BSA}-\mathrm{Cu}_{2} \mathrm{O}$ efficiently released copper ions at the fixed point. The $\mathrm{Cu}^{+}$ion release mechanism in

\section{SN Applied Sciences
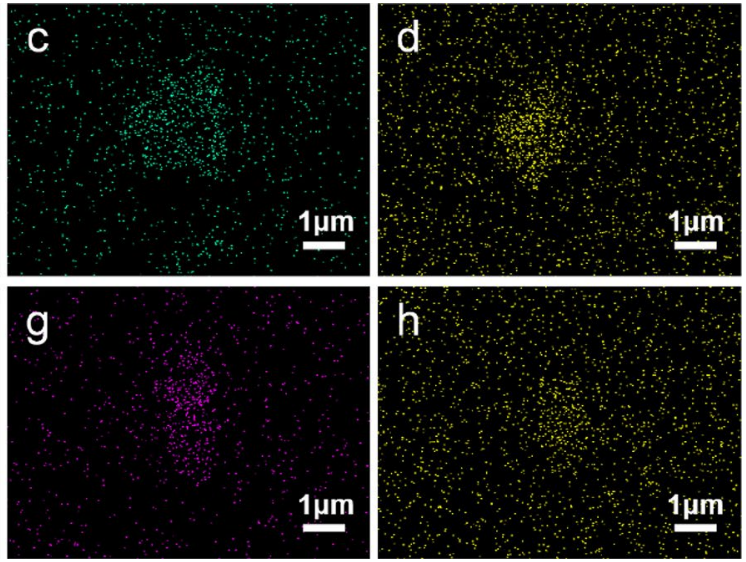

S. aureus (f SEM images, $\mathbf{g}$ elemental mapping of $\mathbf{C}, \mathbf{h}$ elemental mapping of $\mathrm{Cu}$ ). The scale of inset is $1 \mu \mathrm{m}$ 
the alkalescent PBS is shown as the following equation $[38,39]$.

$\mathrm{Cu}_{2} \mathrm{O}+\mathrm{H}_{2} \mathrm{O} \rightarrow 2 \mathrm{Cu}^{+}+2 \mathrm{OH}^{-}$

Compared with other groups (BSA-0- $\mathrm{Cu}_{2} \mathrm{O}$, commercial $\mathrm{Cu}_{2} \mathrm{O}$ and $\mathrm{CuCl}$ ), the amino acid residues of BSA on the surface of $\mathrm{BSA}-\mathrm{Cu}_{2} \mathrm{O}$ might increase the probability of direct contact with bacteria. It was conducive to increasing the concentration of $\mathrm{Cu}^{+}$in the contact position and releasing $\mathrm{Cu}^{+}$to bacteria.

\section{Conclusions}

In summary, a novel biomineralization method to fabricate $\mathrm{Cu}_{2} \mathrm{O} / \mathrm{BSA}$ hierarchical nanocomposite particles is described. $\mathrm{Cu}_{2} \mathrm{O} / \mathrm{BSA}$ NPS had size of $20-50 \mathrm{~nm}$ and were composed of several 6-7 nm $\mathrm{Cu}_{2} \mathrm{O}$ nanocrystals and BSA. $\mathrm{BSA}$ acted as the structure-directing agent, guiding the formation of $\mathrm{Cu}_{2} \mathrm{O} / \mathrm{BSA} \mathrm{NCPs}$. N-terminal peptides, histidine and tryptophan residues of BSA coordinated with $\mathrm{Cu}^{2+}$ and then controlled the nucleation, growth and assembly of $\mathrm{Cu}(\mathrm{OH})_{2}$ at binding sites to form the hierarchical structure. After the reduction reaction, $\mathrm{Cu}_{2} \mathrm{O}$ / BSA NCPs were obtained. The $\mathrm{Cu}_{2} \mathrm{O} / \mathrm{BSA}$ hierarchical structure exhibited excellent antibacterial performance due to the oriented release of copper ions. The good biocompatibility of BSA was beneficial to the contact with cell walls and site-specific release of $\mathrm{Cu}^{+}$. These findings may be useful for the preparation of hierarchical nanostructures by biomineralization process and application in antibacterial field.

\section{Supporting information}

The fluorescence spectra and CD spectra of BSA and $\mathrm{BSA}-\mathrm{Cu}_{2} \mathrm{O}$. The plate photos of S. aureus and E. coli cultured with different samples. The FESEM image and XRD pattern of commercial $\mathrm{Cu}_{2} \mathrm{O}$.

Acknowledgements Financial support of this research from the United Innovation Program of Shanghai Commercial Aircraft Engine Fund (AR909), Municipal Bureau of Quality and Technical Supervision Project of Shanghai (2018) is appreciated.

\section{Compliance with ethical standards}

Conflict of interest The authors declare that they have no conflict of interest.

\section{References}

1. Arivalagan J, Yarra T, Marie B, Sleight VA, Duvernois-Berthet E, Clark MS, Marie A, Berland S (2017) Insights from the shell proteome: biomineralization to adaptation. Mol Biol Evol 34(1):66-77

2. Zeth K, Hoiczyk E, Okuda M (2016) Ferroxidase-mediated iron oxide biomineralization: novel pathways to multifunctional nanoparticles. Trends Biochem Sci 41(2):190-203

3. Wang Z, Huang $P$, Jacobson $O$, Wang Z, Liu Y, Lin L, Lin J, Lu N, Zhang $\mathrm{H}$ et al (2016) Biomineralization-inspired synthesis of copper sulfide-ferritin nanocages as cancer theranostics. ACS Nano 10(3):3453-3460

4. Kang F, Qu X, Alvarez PJJ, Zhu D (2017) Extracellular saccharide-mediated reduction of $\mathrm{Au}^{3+}$ to gold nanoparticles: new insights for heavy metals biomineralization on microbial surfaces. Environ Sci Technol 51(5):2776-2785

5. Wen Y, Dong H, Li Y, Shen A, Li Y (2016) Nano-assembly of bovine serum albumin driven by rare-earth-ion (Gd) biomineralization for highly efficient photodynamic therapy and tumor imaging. J Mater Chem B 4(4):743-751

6. Wang Y, Yang C, Yan X (2017) Hydrothermal and biomineralization synthesis of a dual-modal nanoprobe for targeted nearinfrared persistent luminescence and magnetic resonance imaging. Nanoscale 9(26):9049-9055

7. Xie J, Zheng Y, Ying JY (2009) Protein-directed synthesis of highly fluorescent gold nanoclusters. J Am Chem Soc 131(3):888-889

8. Yilmaz E, Ocsoy I, Ozdemir N, Soylak M (2016) Bovine serum albumin-Cu(II) hybrid nanoflowers: an effective adsorbent for solid phase extraction and slurry sampling flame atomic absorption spectrometric analysis of cadmium and lead in water, hair, food and cigarette samples. Anal Chim Acta 906:110-117

9. Mallakpour S, Nazari HY (2017) Ultrasonic-assisted fabrication and characterization of $\mathrm{PVC}-\mathrm{SiO}_{2}$ nanocomposites having bovine serum albumin as a bio coupling agent. Ultrason Sonochem 39:686-697

10. Sasmal AK, Dutta S, Pal T (2016) A ternary $\mathrm{Cu}_{2} \mathrm{O}-\mathrm{Cu}-\mathrm{CuO}$ nanocomposite: a catalyst with intriguing activity. Dalton Trans 45(7):3139-3150

11. Morales-Guio CG, Liardet L, Mayer MT, Tilley SD, Gratzel M, Hu X (2015) Photoelectrochemical hydrogen production in alkaline solutions using $\mathrm{Cu}_{2} \mathrm{O}$ coated with earth-abundant hydrogen evolution catalysts. Angew Chem Int Ed 54(2):664-667

12. Selim MS, El-Safty SA, El-Sockary MA, Hashem Al, Elenien OMA, El-Saeed AM, Fatthallah NA (2015) Tailored design of $\mathrm{Cu}_{2} \mathrm{O}$ nanocube/silicone composites as efficient foul-release coatings. RSC Adv 5(26):19933-19943

13. Hsu CL, Tsai JY, Hsueh TJ (2016) Ethanol gas and humidity sensors of $\mathrm{CuO} / \mathrm{Cu}_{2} \mathrm{O}$ composite nanowires based on a $\mathrm{Cu}$ throughsilicon via approach. Sens Actuator B Chem 224:95-102

14. Yu W, Li F, Wang H, Alarousu E, Chen Y, Lin B, Wang L, Hedhili $\mathrm{MN}$, Li $\mathrm{Y}$ et al (2016) Ultrathin $\mathrm{Cu}_{2} \mathrm{O}$ as an efficient inorganic hole transporting material for perovskite solar cells. Nanoscale 8(11):6173-6179

15. Emam HE, Ahmed HB, Bechtold T (2017) In-situ deposition of $\mathrm{Cu}_{2} \mathrm{O}$ micro-needles for biologically active textiles and their release properties. Carbohydr Polym 165:255-265

16. Shi X, Xue C, Fang F, Song X, Yu F, Liu M, Wei Z, Fang X et al (2016) Full spectrum visible LED light activated antibacterial system realized by optimized $\mathrm{Cu}_{2} \mathrm{O}$ crystals. ACS Appl Mater Interfaces 8(13):8386-8392 
17. Errokh A, Ferraria AM, Conceicao DS, Ferreira LFV, do Rego AMB, Vilar MR, Boufi S et al (2016) Controlled growth of $\mathrm{Cu}_{2} \mathrm{O}$ nanoparticles bound to cotton fibers. Carbohydr Polym 141:229-237

18. Ren J, Wang W, Sun S, Zhang L, Wang L, Chang J (2011) Crystallography facet-dependent antibacterial activity: the case of $\mathrm{Cu}_{2} \mathrm{O}$. Ind Eng Chem Res 50(17):10366-10369

19. Lee YJ, Kim S, Park SH, Park H, Huh YD (2011) Morphologydependent antibacterial activities of $\mathrm{Cu}_{2} \mathrm{O}$. Mater Lett 65(5):818-820

20. Wang $\mathrm{M}, \mathrm{Ni}$ Y, Liu A (2017) Investigation on the shape evolution of $\mathrm{Cu}_{2} \mathrm{O}$ crystals in the antibacterial process. J Cryst Growth 476:17-24

21. Ma J, Guo S, Guo X, Ge H (2015) Preparation, characterization and antibacterial activity of core-shell $\mathrm{Cu}_{2} \mathrm{O} @ \mathrm{Ag}$ composites. Surf Coat Technol 272:268-272

22. Gao L, Qiu Z, Gan W, Zhan X, Li J, Qiang T (2016) Negative oxygen ions production by superamphiphobic and antibacterial $\mathrm{TiO}_{2} /$ $\mathrm{Cu}_{2} \mathrm{O}$ composite film anchored on wooden substrates. Sci Rep 6:26055

23. Li P, Lv W, Ai S (2015) Green and gentle synthesis of $\mathrm{Cu}_{2} \mathrm{O}$ nanoparticles using lignin as reducing and capping reagent with antibacterial properties. J Exp Nanosci 11(1):18-27

24. Montazer M, Dastjerdi M, Azdaloo M, Rad M (2015) Simultaneous synthesis and fabrication of nano $\mathrm{Cu}_{2} \mathrm{O}$ on cellulosic fabric using copper sulfate and glucose in alkali media producing safe bio- and photoactive textiles without color change. Cellulose 22(6):4049-4064

25. Lee JH (2009) Gas sensors using hierarchical and hollow oxide nanostructures: overview. Sens Actuator B Chem 140(1):319-336

26. Cong L, Xie H, Li J (2017) Hierarchical structures based on twodimensional nanomaterials for rechargeable lithium batteries. Adv Energy Mater 7(12):1601906

27. Belatik A, Hotchandani S, Carpentier R, Tajmir-Riahi HA (2012) Locating the binding sites of $\mathrm{Pb}$ (II) ion with human and bovine serum albumins. PLoS ONE 7(5):e36723

28. Biesinger MC, Lau LWM, Gerson AR, Smart RSC (2010) Resolving surface chemical states in XPS analysis of first row transition metals, oxides and hydroxides: Sc, Ti, V, Cu and Zn. Appl Surf Sci 257(3):887-898

29. Bakare RA, Bhan C, Raghavan D (2014) Synthesis and characterization of collagen grafted poly(hydroxybutyrate-valerate) (PHBV) scaffold for loading of bovine serum albumin capped silver (Ag/BSA) nanoparticles in the potential use of tissue engineering application. Biomacromolecules 15(1):423-435
30. Yang R, Lu X, Huang X, Chen Z, Zhang X, Xu M, Song Q, Zhu L (2015) Bi-component $\mathrm{Cu}_{2} \mathrm{O}-\mathrm{CuCl}$ composites with tunable oxygen vacancies and enhanced photocatalytic properties. Appl Catal B Environ 170:225-232

31. Boulos SP, Davis TA, Yang J, Lohse SE, Alkilany AM, Holland LA, Murphy CJ (2013) Nanoparticle-protein interactions: a thermodynamic and kinetic study of the adsorption of bovine serum albumin to gold nanoparticle surfaces. Langmuir 29(48):14984-14996

32. Gebregeorgis A, Bhan C, Wilson O, Raghavan D (2013) Characterization of silver/bovine serum albumin (Ag/BSA) nanoparticles structure: morphological, compositional, and interaction studies. J Colloid Interface Sci 389(1):31-41

33. Majorek KA, Porebski PJ, Dayal A, Zimmerman MD, Jablonska K, Stewart AJ, Chruszcz M, Minor W (2012) Structural and immunologic characterization of bovine, horse, and rabbit serum albumins. Mol Immunol 52(3-4):174-182

34. Liang $H$, Xin B, Wang $X$ (1998) Equilibrium dialysis study on the interaction between $\mathrm{Cu}(\mathrm{II})$ and HSA or BSA. Chin Sci Bull 43(5):404-409

35. Zhang Y, Wilcox DE (2002) Thermodynamic and spectroscopic study of $\mathrm{Cu}(\mathrm{II})$ and $\mathrm{Ni}(\mathrm{II})$ binding to bovine serum albumin. J Biol Inorg Chem 7(3):327-337

36. Meghana S, Kabra P, Chakraborty S, Padmavathy N (2015) Understanding the pathway of antibacterial activity of copper oxide nanoparticles. RSC Adv 5(16):12293-12299

37. Xiong L, Yu H, Nie C, Xiao Y, Zeng Q, Wang G, Wang B, Lv H et al (2017) Size-controlled synthesis of $\mathrm{Cu}_{2} \mathrm{O}$ nanoparticles: size effect on antibacterial activity and application as a photocatalyst for highly efficient $\mathrm{H}_{2} \mathrm{O}_{2}$ evolution. $\mathrm{RSC}$ Adv 7(82):51822-51830

38. Wang Y, Gao T, Wang K, Wu X, Shi X, Liu Y, Lou S, Zhou S (2012) Template-assisted synthesis of uniform nanosheet-assembled silver hollow microcubes. Nanoscale 4(22):7121-7126

39. Yang Z, Hao X, Chen S, Ma Z, Wang W, Wang C, Yue L, Sun H et al (2019) Long-term antibacterial stable reduced graphene oxide nanocomposites loaded with cuprous oxide nanoparticles. J Colloid Interface Sci 533:13-23

Publisher's Note Springer Nature remains neutral with regard to jurisdictional claims in published maps and institutional affiliations. 